\title{
DESTINADO A SER HOMBRE SÓLO \\ Y PARA SIEMPRE
}

John Milton, Paradise Lost

- Te he escuchado

narrar lo sucedido

antes de venir yo.

Puedo contarte

mi historia, pues quizá

no la conoces.

Resta mucho del día.

Sutilmente

intento, como ves,

que no te marches

invitándote a oir

este relato:

- Te perdí el paraíso,

te perdí

la pista que corrimos

del trabajo que cuesta

andar hacia el amor.

¿Cómo ganarme el pan

que no multiplicaste,

harina, levadura,

fécula,

melaza, engrudo

que no pega

los recortes

de personal

con que me fui derecho

a donde sabes,

a no saber ya nada?

—Descubrirás, quizá,

soles y lunas, 
con masculina luz

y femenina,

porque los sexos son

fuente de vida

que guarda el almacén

de cada estrella.

-Durante casi un año, terriblemente, milagrosamente, como una gestación de dos infértiles, vivimos de la cama, cuidábamos

la hora de dormir, los alimentos

y nuestra propia obra, nuestra obra maestra.

Después de nueve meses alumbramos, al fin, una ausencia que tiene nuestros ojos y el amor de sus padres, fallecidos en el terrible choque al que sobrevivieron. —“Mi más sentido pésame." "Aquí estamos para lo que se ofrezca." "Si necesitan algo, con confianza." "¿Quién diría? Tan jóvenes, en la flor de la edad." "Que Dios los tenga en Su gloria.” (“ ¿Y los cuerpos? ¿Recuperaron algo de los cuerpos?")

- Te pedí de favor, 
HERNÁN BRAVO VARELA

de aquí entre nos,

de en serio júrame,

de no me vayas

a salir con cosas,

de y de qué tal si sí,

de Dios dirá,

de por lo más sagrado,

te pedí, me pediste, quién dijera.

- Es humo, vanidad

o desatino

ocuparse de más,

pues me convierte

en un ser que no ve

lo que le importa, ni puede prevenir

lo que le aguarda, forzándolo a buscar eternamente. 